\title{
Prolonging the shelf life of jasmine (Jasminum grandiflorum) buds by chemical treatments under cold storage condition
}

\section{P Mohanasundari, T Sivakumar, K Krishna Surendar \& M Ganga}

Journal of Agriculture and Ecology

ISSN: 2456-9410

Volume: 6

Journal of Agriculture and Ecology (2018) 6: 85-93 http://doi.org/10.53911/JAE.2018.6211

Volume-6 (December, 2018)

\section{Journal of Agriculture}

\section{and Ecology}

ISSN: 2456-9410

\section{w.}

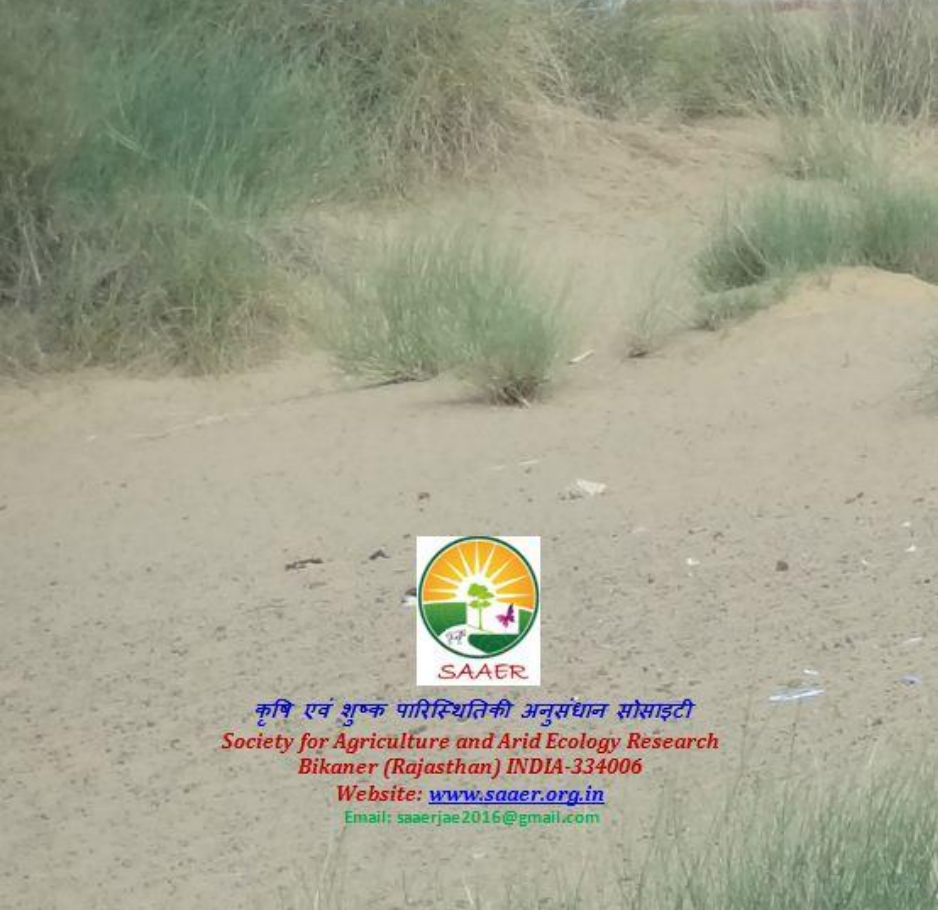




\title{
Prolonging the shelf life of jasmine (Jasminum grandiflorum) buds by chemical treatments under cold storage condition
}

\author{
P Mohanasundari $^{1} \not$, T Sivakumar ${ }^{2}$, K Krishna Surendar $^{3} \&$ M Ganga $^{4}$ \\ ${ }^{1}$ PG Scholar, ${ }^{2}$ Associate Professor (Crop Physiology), Department of Crop Physiology, TNAU, \\ Coimbatore, 641003, India \\ ${ }^{3}$ Assistant Professor (Crop Physiology), Department of Rice, TNAU, Coimbatore, 641003, India \\ ${ }^{4}$ Associate Professor (Horticulture) and Head, TNAU-HRS, Ooty, 643001, India \\ *Corresponding author: P Mohanasundari, E-mail: mohanasundari612@gmail.com
}

\section{Article Info}

Article history

Received: 25 August 2018

Accepted: 03 September

2018

Available online: 27

November 2018

Key Words: Jasminum grandiflorum, shelf life, chemical treatments, freshness index, storage.

\begin{abstract}
Aim of this study is to enhance the shelf life of jasmine flower buds by application of different anti-senescence chemicals to meet out the marketing demand with improved post-harvest quality. The experimental design followed for this study is completely randomized block design with seven treatments, each replicated thrice. The harvested jasmine flowers were treated with different anti-senescence chemicals viz., Silver nanoparticle (SNP) (20ppm), Boric acid (4\%), Sucrose (4\%), NAA (100 ppm), BA (500 ppm), $\alpha$-AIB $(20 \mu \mathrm{M})$ and packed in 200 gauge polypropylene bag without ventilation then stored in cold storage condition. Among the different antisenescence chemical treatments silver nanoparticle $(20 \mathrm{ppm})$ shows positive significant difference in freshness index, flower opening index, color retention index and maintained the shelf life up to 11 days over the control for 7 days.
\end{abstract}

Copyright (C2018 Mohanasundari et al., This is an open access article published under the terms of the Creative Commons Attribution License, which permits unrestricted use, distribution, and reproduction in any medium, provided the original work is properly cited.

Preferred citation: Mohanasundari P, Sivakumar T, Krishna Surendar K \& Ganga M. 2018. Prolonging the shelf life of jasmine (Jasminum grandiflorum) buds by chemical treatments under cold storage condition. Journal of Agriculture and Ecology, 6: 8593; http://doi.org/10.53911/JAE.2018.6211.

\section{Introduction}

Among different jasmine species Jasminum grandiflorum is one of most important and remunerative crop for loose flower production and oil extraction purpose. This species flowers had the high demand in market throughout the year. The jasmine crop is cultivated in the open fields since ancient period for its peculiar and delicate fragrance and also for its aromatic and medicinal value. $J$. grandiflorum is a native of India and popularly called 'Royal Spanish', 'Catalonian', or Italian Jasmine. The leaves are shining dark green with 5-7 leaflets. This is twining shrub with pendulous branches. Flowers are white with a purplish tinge underneath and highly scented. Varieties 
coming under this are pink pin, $\mathrm{CO}-1$, pitchi, thimmapuram, Lucknow etc. J. grandiflorum is grown for extraction of perfume. Jasmine flowers owe their fragrance to a volatile oil present in the epidermal cells of the inner and outer surface of the petals and sepals. The international market prices for jasmine concrete and absolute are around Rs. $12000 / \mathrm{kg}$ and Rs. 19000/kg respectively. Extraction of oil from jasmine is yet to be exploited to its fullest potential in India. Among the scented species, J. angustifolium, J. officinale, J. humile, and $J$. pubescens were useful. The Indian J. grandiflorum have more importance compared with that of Spanish jasmine, both in yield and quality of oil. The jasmine cultivated area is about 8000 ha in India with $56.57 \quad$ MT flower production (www.indiastat.com, 2014-2015). But the post harvest loss is about nearly $20 \%$. It leads to huge loss to farmers as well as retailers and result is fluctuation in market demand. To meet out this market demand we are in place to improve the post harvest quality of these flower buds to extend the shelf life. Hence, the present study entitled "Prolonging the Shelf life of jasmine (Jasminum grandiflorum) buds by chemical treatments under cold storage condition " was carried out to improve the shelf life of Jasminum grandiflorum.

\section{Materials and methods}

\begin{tabular}{lll}
\hline Condition of flowers & Score & $\begin{array}{l}\text { Number of flower buds under this } \\
\text { score }\end{array}$
\end{tabular}

\begin{tabular}{lll}
\hline Almost all buds turgid & 7 & $\mathrm{X}_{1}$ \\
Partial to half open flowers, turgid & 6 & $\mathrm{X}_{2}$
\end{tabular}


Half to full open flowers, turgid

Partial to half open flowers, slightly wilted

Half to full open flowers, slightly wilted

Partial to half open flowers, fully wilted

Half to full open flowers fully wilted
5

4

3

2

1
$\mathrm{X}_{3}$

$\mathrm{X}_{4}$

$\mathrm{X}_{5}$

$\mathrm{X}_{6}$

$\mathrm{X}_{7}$

Freshness index (FI) was computed using the following formula:

$$
\mathrm{FI}=\frac{\left(7 \times \mathrm{X}_{1}\right)+\left(6 \times \mathrm{X}_{2}\right)+\left(5 \times \mathrm{X}_{3}\right)+\left(4 \times \mathrm{X}_{4}\right)+\left(3 \times \mathrm{X}_{5}\right)+\left(2 \times \mathrm{X}_{6}\right)+\left(1 \times \mathrm{X}_{7}\right)}{\left(\mathrm{X}_{1}+\mathrm{X}_{2}+\mathrm{X}_{3}+\mathrm{X}_{4}+\mathrm{X}_{5}+\mathrm{X}_{6}+\mathrm{X}_{7}\right) \times 7} \times 100
$$

\section{Flower opening index}

The flower opening index was measured by the following score.

\begin{tabular}{lcc}
\hline Stage of flowers & Score & Number of flower buds under this score \\
\hline Unopened buds & 0 & $\mathrm{X}_{1}$ \\
Slightly opened & 1 & $\mathrm{X}_{2}$ \\
Half opened & 2 & $\mathrm{X}_{3}$ \\
Full opened & 3 & $\mathrm{X}_{4}$ \\
\hline
\end{tabular}

Flower opening index (FOI) was computed using the following formula,

$$
\mathrm{FOI}=\frac{\left(0 \times \mathrm{X}_{1}\right)+\left(1 \times \mathrm{X}_{2}\right)+\left(2 \times \mathrm{X}_{3}\right)+\left(3 \times \mathrm{X}_{4}\right)}{\left(\mathrm{X}_{1}+\mathrm{X}_{2}+\mathrm{X}_{3}+\mathrm{X}_{4}\right) \times 3} \times 100
$$

\section{Color retention index}

The retention of white colour of jasmine flowers was recorded by the following score

\begin{tabular}{lccc}
\hline Flower colour development during storage & Score & $\begin{array}{l}\text { Number of flower buds under this } \\
\text { score }\end{array}$ \\
\hline Bright pink with white & 9 & $\mathrm{X}_{1}$ \\
Dull pinkish white & 8 & $\mathrm{X}_{2}$ \\
Cream or yellowish & 7 & $\mathrm{X}_{3}$ \\
1 to $10 \%$ brown & 6 & $\mathrm{X}_{4}$ \\
11 to $15 \%$ brown & 5 & $\mathrm{X}_{5}$ \\
16 to $50 \%$ brown & 4 & $\mathrm{X}_{6}$
\end{tabular}


51 to $75 \%$ brown

3

2

1
$\mathrm{X}_{7}$

$\mathrm{X}_{8}$

$\mathrm{X}_{9}$

Colour retention index (CRI) was computed by using the following formula:

$$
\mathrm{CRI}=\frac{\left(9 \times \mathrm{X}_{1}\right)+\left(8 \times \mathrm{X}_{2}\right)+\left(7 \times \mathrm{X}_{3}\right)+\left(6 \times \mathrm{X}_{4}\right)+\left(5 \times \mathrm{X}_{5}\right)+\left(4 \times \mathrm{X}_{6}\right)+\left(3 \times \mathrm{X}_{7}\right)+\left(2 \times \mathrm{X}_{8}\right)+\left(1 \times \mathrm{X}_{9}\right)}{\left(\mathrm{X}_{1}+\mathrm{X}_{2}+\mathrm{X}_{3}+\mathrm{X}_{4}+\mathrm{X}_{5}+\mathrm{X}_{6}+\mathrm{X}_{7}+\mathrm{X}_{8}+\mathrm{X}_{9}\right) \times 9} \times 100
$$

\section{Shelf life}

Shelf life of flowers was assessed by recording the number of days up to which 50 per cent or more flowers kept fresh $(50 \%$ of Freshness index score). The time taken for the development of necrotic symptoms was recorded and the shelf life was determined as the number of days taken from placing of the loose flowers till wilting and fading of petals of these loose flowers Madhu (1999).

\section{Statistical analysis}

Statistical analysis for the CRD viz., computation of mean, standard error and critical difference was carried out using Excel and SPSS 9.4 packages. The required graphs were drawn using MS Excel software packages. The per cent values were first transformed to angular arcsine values before the analysis wherever it necessary. The data were tested for at five per cent level (*)for significance and non significant (NS). Wherever the treatment differences were found significant (' $F$ ' test) critical differences were worked out at five per cent probability level and the values furnished. Differences between the treatments were determined using Duncan's test.

\section{Results and Discussion}

\section{Freshness index}

Result on FI of $J$. grandiflorum shows that under cold storage condition flower buds treated with SNP $20 \mathrm{ppm}\left(\mathrm{T}_{2}\right)$ has registered maximum FI with $94.19 \%$ followed by AIB $(20 \mu \mathrm{M})\left(\mathrm{T}_{7}\right)$ with $93.36 \%$ FI over the control $\left(\mathrm{T}_{1}\right)(86.76 \%)$. Freshness index varied among the treatments, storage condition and jasmine species (Table 1). Maximum freshness index recorded by best treatments may be the effect of packaging material that reduce the rate of respiration by creating a sort of modified atmosphere with limited oxygen and higher carbon dioxide concentrations. The limited oxygen concentration can retard the rate of respiration as oxygen is an essential factor needed for this process. The findings of Beura \& Singh (2003) supported the results of the present experiment with a view that minimum weight loss, more freshness and higher membrane stability index in gladiolus cultivars might be due to reduction of respiration with limited oxygen and higher carbon dioxide concentration. These findings also have close agreement with the observations recorded by in gladiolus cultivars and found minimum weight loss, 
more freshness and good membrane stability index.

Table 1. Effect of different anti-senescence chemical treatment and cold storage condition on freshness index of Jasminum grandiflorum

\begin{tabular}{llllllll}
\hline Treatments & 1DAT & 3 DAT & 5 DAT & 7 DAT & 9 DAT & 11 DAT & Mean \\
\hline $\mathrm{T}_{1}$-Control & 97.14 & 96.57 & 88.57 & 85.14 & 87.42 & 65.71 & 86.76 \\
$\mathrm{~T}_{2}$ & 100.00 & 96.57 & 96.57 & 94.28 & 90.85 & 86.85 & 94.19 \\
$\mathrm{~T}_{3}$ & 93.14 & 98.28 & 96.00 & 96.00 & 84.00 & 70.85 & 89.71 \\
$\mathrm{~T}_{4}$ & 99.42 & 91.42 & 90.85 & 85.71 & 84.00 & 60.57 & 85.33 \\
$\mathrm{~T}_{5}$ & 96.00 & 86.85 & 74.28 & 72.00 & 70.85 & 64.57 & 77.43 \\
$\mathrm{~T}_{6}$ & 99.42 & 96.57 & 96.00 & 87.42 & 77.14 & 68.00 & 87.43 \\
$\mathrm{~T}_{7}$ & 99.42 & 98.28 & 97.71 & 97.14 & 86.85 & 80.76 & 93.36 \\
\hline Mean & 97.79 & 94.93 & 91.43 & 88.24 & 83.02 & 71.04 & 87.74 \\
$\mathrm{~S}$. Ed. & $\mathrm{NS}$ & 2.34 & 1.17 & 2.38 & 2.12 & 1.15 & \\
$\mathrm{CD}(5 \%)$ & $\mathrm{NS}$ & $5.01^{*}$ & $2.51^{*}$ & $5.10^{*}$ & $4.55^{*}$ & $2.46^{*}$ &
\end{tabular}

DAT- day after treatment

*Significant at $5 \%$ probability level

Flower opening index

Minimum FOI (13.09\%) was recorded by SNP $20 \mathrm{ppm}\left(\mathrm{T}_{2}\right)$ followed by AIB $(20 \mu \mathrm{M})\left(\mathrm{T}_{7}\right)$ with $14.04 \%$ after 11 days of treatment under cold storage condition over the control. Flower opening index was found to be significantly influenced by MAP in the present study. Both under ambient and cold room conditions, least FOI were registered by SNP in J. grandiflorum (Table 2). Some of the earlier conclusions drawn about flower opening in cut roses have been shown to be dependent on carbohydrate status in the petals (Kenis et al.,1985). Petal growth associated with flower bud opening results from cell expansion, which requires the influx of water and carbohydrates into petal cells (Reid 1988). According to Vandoorn \& Witte (1991) who found that reduced water status of flowers is known to record the lowest flower opening under ambient conditions while in MAP low level of $\mathrm{O}_{2}$ in the packages would record least FOI (Devecchi et al. 2003).

Table 2. Effect of different anti-senescence chemical treatment and cold storage condition on flower opening index of Jasminum grandiflorum

\begin{tabular}{llllllll}
\hline Treatments & 1 DAT & 3 DAT & 5 DAT & 7 DAT & 9 DAT & 11 DAT & Mean
\end{tabular}




\begin{tabular}{llllllll}
\hline $\mathrm{T}_{1}$-Control & 6.60 & 8.00 & 26.60 & 34.66 & 41.33 & 65.33 & 30.42 \\
$\mathrm{~T}_{2}$ & 0.00 & 8.00 & 9.30 & 9.30 & 21.33 & 30.60 & 13.09 \\
$\mathrm{~T}_{3}$ & 2.60 & 16.00 & 17.30 & 17.30 & 24.00 & 30.60 & 17.97 \\
$\mathrm{~T}_{4}$ & 1.30 & 8.00 & 20.00 & 21.30 & 38.60 & 49.30 & 23.08 \\
$\mathrm{~T} 5$ & 9.30 & 30.60 & 65.33 & 65.33 & 69.33 & 77.33 & 52.87 \\
$\mathrm{~T}_{6}$ & 1.30 & 8.00 & 65.33 & 65.33 & 69.30 & 77.33 & 47.77 \\
$\mathrm{~T}_{7}$ & 0.00 & 4.00 & 5.30 & 9.30 & 28.00 & 37.66 & 14.04 \\
\hline Mean & 3.01 & 11.8 & 29.88 & 31.79 & 41.70 & 52.59 & 28.46 \\
$\mathrm{~S}$. Ed. & 0.03 & 0.29 & 0.26 & 0.79 & 0.75 & 1.69 & \\
$\mathrm{CD}(5 \%)$ & $0.07^{*}$ & $0.62 *$ & $0.55^{*}$ & $1.69 *$ & $1.60^{*}$ & $3.63^{*}$ & \\
\hline
\end{tabular}

DAT- day after treatment

*Significant at $5 \%$ probability level

Color retention index

Maximum CRI (98.66\%) was observed in SNP $20 \mathrm{ppm}\left(\mathrm{T}_{2}\right)$ and AIB $(20 \mu \mathrm{M})\left(\mathrm{T}_{7}\right)$ in J.grandiflorum. They were on par with each other after 11 days of treatment when stored in cold storage condition. The color retention index was also significantly influenced by treatments and storage conditions. Under cold storage condition SNP in J.grandiflorum registered maximum color retention index. However none of the treatment recorded less than 50 per cent color retention index under cold storage condition but it declined from 100 to 75 per cent ( 3 to 11 days) in $J$. grandiflorum (Table 3 ). The yellowing of florets during modified atmospheric packing storage has been reported due to the losses of membrane integrity, protein and chlorophyll caused by lipid peroxidation and hydroperoxides in broccoli was also observed by Watada et al. (1990). Color retention of the flowers could be related to the activity of polyphenol oxidase and its action on phenolic content in flowers. Increasing phenolic compounds during later stages causes the browning of flowers where in color retention index is low. In the present study, 100 per cent color retention index was associated with the least activity of phenol compound under cold storage condition. In case of ambient storage condition also, the maximum color retention index was associated with the lowest phenol content. This explains that enzymatic discoloration is caused by the oxidation of phenol compounds due the action of polyphenol oxidase which leads to the browning in plants during wilting (Lee \& Whitaker, 1995). Tian et al. (2002), demonstrated the positive effect of modified atmospheric storage reduces the activity of polyphenol oxidase and ethylene production. But also MAP package delay the development of browning in flowers it has been attributed to $\mathrm{CO}_{2}$ inhibition activity on 
the enzyme polyphenol oxidase. Day (1996), explained the significant role of modified atmospheric storage due to high level of $\mathrm{CO}_{2}$ or of colorless quinines may inhibit

Table 3. Effect of different anti senescence chemical treatment and cold storage condition on colour retention index of Jasminum grandiflorum

\begin{tabular}{llllllll}
\hline Treatments & 1 DAT & 3 DAT & 5 DAT & 7 DAT & 9 DAT & 11DAT & Mean \\
\hline $\mathrm{T}_{1}$-Control & 100.00 & 98.22 & 96.00 & 91.11 & 89.33 & 81.33 & 92.67 \\
$\mathrm{~T}_{2}$ & 100.00 & 100.00 & 100.00 & 98.22 & 96.88 & 96.88 & 98.66 \\
$\mathrm{~T}_{3}$ & 100.00 & 99.55 & 99.11 & 96.11 & 94.77 & 89.33 & 96.48 \\
$\mathrm{~T}_{4}$ & 100.00 & 99.55 & 99.11 & 99.11 & 93.77 & 67.55 & 93.18 \\
$\mathrm{~T}_{5}$ & 99.55 & 97.33 & 80.00 & 80.00 & 79.11 & 75.55 & 85.26 \\
$\mathrm{~T}_{6}$ & 100.00 & 99.55 & 99.11 & 98.66 & 91.55 & 76.44 & 94.22 \\
$\mathrm{~T}_{7}$ & 100.00 & 100.00 & 100.00 & 99.55 & 92.00 & 88.00 & 96.59 \\
\hline Mean & 99.94 & 99.17 & 96.19 & 94.68 & 91.06 & 82.15 & 93.87 \\
$\mathrm{~S}$. Ed. & $\mathrm{NS}$ & 2.36 & 2.52 & 1.33 & 2.97 & 1.26 & \\
$\mathrm{CD}(5 \%)$ & $\mathrm{NS}$ & $5.07 *$ & $5.42^{*}$ & $2.86^{*}$ & $6.38^{*}$ & $2.70^{*}$ & \\
\hline
\end{tabular}

DAT- day after treatment

*Significant at $5 \%$ probability level Shelf life

In $J$. grandiflorum the treatment of SNP $20 \mathrm{ppm}\left(\mathrm{T}_{2}\right)$ was significant and recorded maximum shelf life of 11 days under cold storage condition. AIB $20 \mu \mathrm{M}\left(\mathrm{T}_{7}\right)$ also found to be significant on shelf life enhancement over the control $\left(T_{1}\right) 7$ days and on par with each other. It could be observed in the present study that shelf life (days) was significantly affected by all the treatments and storage conditions. Flower buds of Jasminum grandiflorum treated with silver nanoparticle (20 ppm) stored in cold storage registered the maximum shelf life of 11days and this treatment is significantly superior over the other treatments and control polyphenol oxidase, resulting in the inhibition of enzymatic discolouration in MAP. 
life under cold storage condition. Jawaharlal et al.(2012), further explained that increase in shelf life under cold storage condition in jasmine. These findings strongly supported the results of the present study.

\section{Conclusion}

This study concluded that flower bud stored in cold storage condition with post harvest anti senescence chemical (SNP 20 ppm) treatment has registered highest shelf life by the way of maintained higher freshness index, flower opening index and color retention index. During peak flowering season farmers facing long term storage problem due to its short shelf life of this flower nature. The present study reduces this constraint.

\section{References}

Beura S \& Singh R. 2003. Effect of storage temperature and wrapping material on postharvest life of gladiolus cultivar Her Majesty. Journal of Ornamental Horticulture, 6(4): 322-327.

Day BPE. 1996. High oxygen modified atmosphere packaging for freh prepared produce. Post harvest News Informention, 7: 31-34.

Devecchi M, Van Meeteren U, De Wild J \& Woltering E. 2003. Effects of low $\mathrm{O}_{2}$ on cut rose flowers at suboptimal temperature. Acta Horticulturae, 628: 855-861.

Jawaharlal M, Thamaraiselvi S \& Ganga M. 2012. Packaging technology for export of jasmine (Jasminum sambac Ait.) flowers. Journal of Horticultural Science, 7(2): 180-189.

Kenis JD, Silvente ST \& Trippi VS. 1985. Nitrogen metabolism and senescence associated changes during growth of carnation flowers (Dianthus caryophyllus). Physiologia Plantarum, 65: 455-459.

Lee CY \& Whitaker JR. 1995. Enzymatic browning and its prevention: ACS Publications,600, 2-7.

Madaiah D \& Reddy T. 1994. Influence of polyethylene packaging on the postharvest life of tuberose (cv. Single) florets. Karnataka Journal of Agricultural Science, 7(2): 154-157.

Madhu GR. 1999. Studies on the effect of different packaging materials and chemicals on the post-harvest life of jasmine flowers. M.Sc.(Ag.) thesis. Annamalai

Univeristy, Annamalainagar, Tamil Nadu.

Nagaraja G, Gowda J \& Farooqi A. 1999. Shelf life of tuberose flowers as influenced by packaging and ventilation. Karnataka Journal of Agricultural Sciences, 12(1/4): 239242.

Nirmala S \& Reddy TV. 1993. Extension of shelf life of Jasminum multiflorum through packaging. Journal of Maharashtra Agricultural University, 27: 272-276.

Reid MS. 1988. The role of ethylene in flower senescence. Paper presented at the IV International Symposium on 
Postharvest Physiology of Ornamental Plants 261.

Thamaraiselvi S, Jawaharlal M, Ganga M \& Varadharaju N. 2010. Packaging technology for long term storage of jasmine (Jasminum sambac Ait.) flowers. Journal of Ornamental Horticulture, 13(3): 171-181.

Tian S, Xu Y, Jiang A \& Gong Q. 2002. Physiological and quality responses of longan fruit to high $\mathrm{CO}_{2}$ and $\mathrm{O}_{2}$ atmosphere in storage. Postharvest Biology and Technology, 24: 335-340.
Vandoorn WG \& witte YD. 1991. Effect of dry storage on bacterial counts in stems of cut rose flowers. Physiology Plant, 3 : 15-22.

Watada AK \&Yamaguchi N. 1990. Physiological activities of partially processed fruits and vegetables. Food technology, 5(2): 116. 